\title{
Exploring language game strategy for teaching Arabic speaking skills
}

\author{
Dr. Ahmed Ezzat \\ City University College of Ajman, PO box 18484, UAE
}

\section{Abstract}

The current research study aims to examine the language game strategy as an effective teaching method of Arabic language speaking skill. Participants of the study were two groups of first graders in one of the Egyptian schools. The researcher selected a number of sub-skills and designed a set of activities, after that two groups of students were assigned as control and experimental groups. The experimental group used to take their classes in speaking with the language game strategy while the control group students used to take their classes with the traditional way of teaching. The findings of the study found that teaching Arabic speaking with the language game strategy is an effective way after comparing the results of both control and experimental groups in the pre and posttests.

Keywords: Arabic Language, teaching methods, language game strategy

DOI: $10.7176 / \mathrm{JEP} / 10-30-11$

Publication date:October $31^{\text {st }} 2019$

\section{Introduction and literature review}

Arabic language is considered as the main pillar for the first grade students in the Arab regions(Abu-Rabia \& Siegel, 2003). They can acquire knowledge and information in other subjects, as well as through which they express their thoughts, feelings and emotions. Arabic has four main skills: listening, speaking, reading, writing, and the skill of speaking is one of the most important Language skills, through which individuals interact with each other in different situations of life(Ishrat Aamer Qureshi, 2013). Speaking in any language is measured as is a tool for transferring human thoughts, feelings and needs to other people living with them(Introna, 2009) with the importance of teaching speaking to beginners, and the need to master their skills At the primary level by applying different strategies.

One of these strategies is the language games strategy, which makes the student active and effective during the acquisition of skills through interaction with the activities. As it is a strategy based on collective interaction between students in the framework of organized competition (Cressman \& Apaloo, 2018). This strategy also supports linguistic integration (Chamot, 2005), which is matching with the Arabic language courses at the primary level.

This strategy also contributes to differentiate between students so they can acquire the main language skills through the practice of playing activities, as well as these activities acquires students teamwork skills, cooperative learning skills, problem-solving skills, and decision-making skills, which The main skills that make the student social and able to communicate with others effectively(Tuma, J. M., \& Pratt, J. M. (1982). Clinical child psychology practice and training: A survey. \ldots of Clinical Child \& Adolescent Psychology, 137(August 2012) et al., 2003).

Moreover, the strategy of language games helps students to acquire key speaking skills, activities and enables student to understand themselves and accept each other's. Additionally to discover the environment in which they live.

\section{- The importance of language games strategy for the first grade students:}

In recent decades there had been a set of research studies of the implementation of games in learning is schools in order to investigate if this strategy can have any effect in assisting different educational goals(Tuma, J. M., \& Pratt, J. M. (1982). Clinical child psychology practice and training: A survey. Idots of Clinical Child \& Adolescent Psychology, 137(August 2012) et al., 2006). Actually, the profits provided in the last sections, seem to present some worries when schools apply the strategy of language games to support acquiring different speaking skills in the primary schools in general and for first graders in particular (Marcelioniene, 2012). Research studies on the application of language games strategy in school curricula focused on the effect of the 
tools in the games on learning itself(Tuma, J. M., \& Pratt, J. M. (1982). Clinical child psychology practice and training: A survey. Ildots of Clinical Child \& Adolescent Psychology, 137(August 2012) et al., 2010a). From this type of studies, knowledge of material in the content connected directly with knowledge applied in the games. One study came with the same idea had been conducted with around 250 students from fourth graders. The participants received a number of games designed by the research team. The games were designed for English Language and Mathematics. The findings of the research came up with a positive description of the language games but for the used tools of the designed games (Gros, 2007).

From all of the above, we can notice the following benefits of the language game strategy:

- It can obtain a type of social interaction between students and their environment; for the purpose of learning process and development behavior and skills (Juzeleniene, Mikelioniene, Escudeiro, \& Carvalho, 2014).

-It can activate mental abilities, and highlight the talents of students (Sanoudaki \& Thierry, 2015).

- It can develop the values of cooperation, and train students socially, respect the rights of others, and respect laws(Tuma, J. M., \& Pratt, J. M. (1982). Clinical child psychology practice and training: A survey. \ldots of Clinical Child \& Adolescent Psychology, 137(August 2012) et al., 2010b).

- It can explore new concepts; help assess the understanding of the meanings of things(Al-Momani, Hussin, \& Hamat, 2014).

- It can contribute to the individualization of education, and organize it to face individual differentia nans between students(Bykova, Kuvaldina, Mashkovtseva, \& Malova, 2018).

- Enhance learning experiences, and give an opportunity for fruitful review, of what has already been learned through it(Deye, N., Vincent, F., Michel, P., Ehrmann, S., Da Silva, D., Piagnerelli, M., ... Laterre, P.-F. (2016). Changes in cardiac arrest patientsâ€TM temperature management after the 2013 â€œTTMâ€ trial: Results from an international survey. Annals of Intensive et al., 2015).

- Help students to express themselves(Tuan \& Mai, 2015).

- Contribute to motivation of students(Vandercruysse, Vandewaetere, Cornillie, \& Clarebout, 2013).

- Language games strategy contributes significantly in creative learning(Sari \& Chen, 2013), the development of exploration(Hardy \& Hessel, 2007), experimentation(Tuma, J. M., \& Pratt, J. M. (1982). Clinical child psychology practice and training: A survey. \ldots of Clinical Child \& Adolescent Psychology, 137(August 2012) et al., 2010b), and reduce the gap between what is happening in the classroom and what is happening in everyday situations, with applications of life language in addition to the opportunity to change the traditional role of both teacher and students. In this regard, the teacher will take the responsibility of preparation, organization, follow-up and distribution of tasks and evaluation, which enables students to acquire the main skills of the language.

- Games contribute in suggesting solutions to the issues faced by students during their study, which helps them making the appropriate decisions(Tuma, J. M., \& Pratt, J. M. (1982). Clinical child psychology practice and training: A survey. Vldots of Clinical Child \& Adolescent Psychology, 137(August 2012) et al., 2014).

- Types of language games:

-Group games competitions based on verbal expressions(Ying \& Blanchfield, 2010).

- Individual quiz games, for issues that require an individual efforts in learning (Fabricatore \& López, 2012).

- Language games, or what is called structured play (Kim \& Kellogg, 2007).

- Motor games accompanied by language activities (Garzotto, Gelsomini, Oliveto, \& Valoriani, 2014).

- Games that develop individual thinking skills, such as card games, and expressive images (Kordaki \& Gousiou, 2017).

- Games based on visual skills for distinguishing, and expression(Howland \& Good, 2015).

- Play with the discovery of language contents(A. Smith \& Vaux, 2003).

- Games representation of positions (simulation) (Whitton, 2014).

- Free acting games (M. S. Smith, 2009).

- $\quad$ Research terms and key words:

1. Language Games Strategy: The strategy of language games in research means "collective language activities based on positive interaction by students in the framework of organized competition; to develop the skills of 
speaking in the first grade students through the practice of organized and purposeful play; to achieve the goals of the learner." (Education, 2017).

2. Skill: a performance characterized by a high degree of speed, accuracy and mastery; as a result of the practice of repeated, gradual and continuous training, through which the learner exerted the necessary effort to acquire the skill (Othman \& Mohamad, 2014).

3. Speaking skills: the process that includes intellectual, linguistic, phonetic and indicative aspects, with the aim of transferring information, knowledge, experiences, ideas and opinions from one person to another verbally transfer from the listener to the site of understanding, interaction and response in different situations of life (Sadiku, 2015).

4. Speaking skills in research means: linguistic performance that enables first grade students to express their ideas and knowledge in a way that allows the listener to understand and absorb by employing the main speaking skills: using the elements of language correctly in speaking, speaking expressing life situations, talking to communicate with Others (Boonkit, 2010).

Research Procedures:

- $\quad$ The search proceeds as followed:

1. Prepare a list of the necessary speaking skills for the first grade students, through the following:

a) Studying the nature of primary education in terms of importance, objectives and content.

b) Studying the objectives of teaching Arabic at the primary level in general, and the objectives of teaching the specific language of these students in particular.

c) The results of studies and research conducted in the field of Arabic and foreign speaking skills in primary education.

d) Studying the Arabic and foreign literature in the field of teaching the skills of speaking at the stage of primary education.

e) Identifying the necessary speaking skills from the previous axes, and present them to a group of arbitrators to verify their sincerity, and bring them to the final image.

2. Determine the extent to which first grade students are able to speak, through the following points:

Prepare a test in speaking skills to determine the extent to which first grade students are able to speak, through the following:

a) Prepare the initial image of the test in the light of the list of skills produced from the previous procedure.

b) Present the initial image of the test to a group of teachers specialized in the field;

c) Apply the test to a group of first-grade students; to check the suitability of the test for students in this grade.

d) Finalize the test in the light of the opinions expressed by the judges and the results of the exploratory application.

e) Prepare a key to correct the test through the following:

f) Prepare the initial image of the key in the light of what was reached in the previous procedure.

g) Present the initial image of the key to a group of arbitrators specialized in the field;

h) Put the final key in the light of the views of the judges.

i) Interviews with a sample of students of the first grade of primary, and record their conversations.

j) Open interviews with teachers of these students to obtain information about their academic performance and behavior

k) Within the classroom, determine how well the first graders of these skills are able from their perspective.

3. Identify the components of the proposed unit to develop some of the speaking skills of the first grade students using the language games strategy, through the following points:

a) Identify the components of the language games strategy through educational literature, foreign studies and research.

b) Determine the objectives of the proposed unit. 
c) Prepare the content of the proposed unit by employing the skills reached; which was approved by $80 \%$ or more of the specialists' opinions.

d) Divide the unit into a set of lessons.

e) Determine the method of teaching.

f) Identify of activities.

g) Determine the methods of evaluation.

h) Identify exploratory experimentation of the unit and making the necessary adjustments.

i) Reach the final image of the proposed unit.

4. Identify the effectiveness of the proposed unit using the language games strategy in the development of some speaking skills among first grade students, through the following:

5. Selecting a group of first graders from a public school and dividing them into two groups. The first group is an experimental group where the proposed unit is based on the strategy of language games, while the control group is taught in the traditional way.

6. Pre-test is given to both of the experimental and the control groups.

7. Application of the proposed unit lessons using the language games strategy with the experimental group.

8. Applying the post-test to the two groups (experimental and control).

Correct the test using the correction key.

9. Reaching the results and treating them statistically.

10. Make recommendations and suggestions.

\section{Problem statement}

The main idea of research study is to identify the effectiveness of language games strategy in developing some of Arabic speaking skills of first grade students (Snyder \& Beavis, 2004). In this regard, the present research has sought to answer the following research question:

The main question of this research study is: What is the effect of language games strategy on the development of some of the speaking skills of first graders? This main question is divided into the following sub-questions:

1. What are the appropriate speaking skills for first grade students?

2 - How well can the first grade students from the previous speaking skills?

3 - What are the components of the proposed unit to develop some of the skills of speaking among first grade students using language games strategy?

4 - What is the effectiveness of the proposed unit using the strategy of language games in the development of some of the skills of speaking among first grade students?

i. $\quad$ Research objectives:

This research draws its importance from the following ideas:

- Language games strategy enables teachers and learners to acquire key language skills in vital and essential situations, which contributes to build the student's personality in a balanced manner through the collective interaction between students in the educational situations; to achieve the desired goals (Bastami Bandpay, 2016).

- The results of this research, and by focusing on the importance of the strategy of language games, may benefit researchers in the field of educational techniques to conduct other research on the aspects of this topic.

- Determine the importance of language games strategy in the educational field, so as to benefit from them in the development of the other language skills.

- Provide an educational approach by modifying the proposed unit to present the language games strategy in Arabic language.

- Provide teachers in different educational stages and different courses with a realistic view of the extent to which the students of the first grade benefit from the experience of the strategy of language games.

- The current research seeks to establish a scientific basis from the educational and technical terms to use the strategy of language games.

- Moreover, the current research study may cover the research gap in the era of Arabic language games strategy 
as it is stated in the literature(Tuma, J. M., \& Pratt, J. M. (1982). Clinical child psychology practice and training: A survey. \ldots of Clinical Child \& Adolescent Psychology, 137(August 2012) et al., 2008).

\section{Methods \\ Research design}

The data of this research study would be collected and analyzed quantitatively through selecting two groups from first graders in a primary school in Egypt. Quantitative research is known as the systematic exploration of a certain phenomenon by collecting measurable data and doing statistical, mathematical or computational procedures on them. Quantitative research collects data from existing and latent samples (Queirós, Faria, \& Almeida, 2017).

Participants:

100 students from grade one in a primary school in Egypt. 50 fist graders were in one group as an experimental group and 50 were as a control group. The investigated teaching strategy; Language gaming strategy; was applied with the experimental group. The mentioned strategy used in teaching one unit to the experimental group while the control group used to take the same unit with the traditional teaching method.

\section{Criteria for selecting language games:}

- Should contain the spirit of competition and challenge.

- Shouldn't depart from the general framework planned.

- Should be in specific and clear objectives in advance.

- Should be suitable for students' experiences and abilities.

- Should be exciting, fun to check motivation for learning.

- Should take into its considerations the age and educational characteristics of learners.

- The game should not depart from its general framework of the ethics of the region where it would be applied.

- The role of the students should be clear and specific.

- Should into account the time whether the time of the lesson, or the time of division of game for the participants.

- Should record the observations of the teacher on his students, and on the game; in order to provide feedback, and diagnose the growth of students, in terms of gaining the required expertise.

- Should fit the numbers of learners involved.

- Should have possibility to execute the game inside the classroom.

- Should include each set of games in difficulty.

- Should be easy and uncomplicated in the learners used phrases, words, and be useful and meaningful to them at this stage.

- Should match the material possibilities of the school.

\section{Conclusion and recommendations:}

\section{Results for the first question: What are the appropriate speaking skills for first graders?}

Speaking skills were determined by constructing a questionnaire for this purpose, where the researcher relied on the modern trends in the field of teaching speaking in the primary stage. The questions of the recent research studies came to ensure both of validity and consistency of the questions of the questionnaire. The points of the questionnaire were presented to six specialists in curricula and teaching methods of Arabic language and fourteen mentors and teachers of the Arabic language at the primary stage, then were judged in order to obtain skills that are approved by $80 \%$ or more of the arbitrators, and then used these skills in the tools of the current research, the following is the final description of these skills:

The final image of the speaking skills required for first grade primary students, and includes skills that have received $80 \%$ or more of the opinions of the judges, namely: 
Table (1)

Percentages of the suitability of each of the main speaking skills of first graders in the light of the opinions of the arbitrators

\begin{tabular}{|l|l|}
\hline S.N & Key speaking skills \\
\hline \multicolumn{2}{|l|}{ First - speaking skills, divided into: } \\
\hline \multicolumn{2}{|l|}{ Level $\mathbf{1}$ - Uses language elements correctly while speaking: } \\
\hline 1 & Pronounce Arabic sounds correctly. (90\%) \\
\hline 2 & Use vocabulary correctly while speaking. (90\%) \\
\hline 3 & Use correct language structures. (90\%) \\
\hline 4 & Arrange ideas while talking. (95\%) \\
\hline Level II - speaks about life situations: \\
\hline 5 & describes a favorite place (class or home). (90\%) \\
\hline 6 & tells personal experience. (90\%) \\
\hline Level 3 - Talk to others: \\
\hline 7 & knows himself to others. (90\%) \\
\hline 8 & Orally communicates with others. (90\%) \\
\hline 9 & Nonverbal communication is used appropriately. (80\%) \\
\hline 10 & Expresses his opinion while talking to others. (90\%) \\
\hline 11 & speaks without repeating certain words (verbal necessities). (80\%) \\
\hline 12 & speaks in a clear and audible voice to listeners. (80\%) \\
\hline
\end{tabular}

By reaching the main speaking skills of the first grade students, the first question was answered.

2. Results of the second research question: How well are first-graders with previous speaking skills? To answer this question, the following procedures were followed:

1. Apply the speaking test to determine the extent to which the first graders are able to speak the mentioned speaking skills.

2. Identify the speaking skills in which the first graders have some weakness points. 
Table (2)

The results of the application of speaking test on the first grade pupils

\begin{tabular}{|c|c|c|c|c|c|c|}
\hline \multicolumn{2}{|c|}{$\begin{array}{l}\text { Students with } 50 \% \text { or } \\
\text { less on the test }\end{array}$} & \multicolumn{2}{|c|}{$\begin{array}{l}\text { Students with } 50 \% \text { or } \\
\text { more on the test }\end{array}$} & \multirow[t]{2}{*}{$\mathbf{N}$} & \multirow[t]{2}{*}{ Skill } & \multirow[t]{2}{*}{ 每 } \\
\hline Percentage & Number & Percentage & Number & & & \\
\hline $33, \% 35$ & 53 & $66, \% 64$ & 97 & $\begin{array}{l}15 \\
0\end{array}$ & pronounce Arabic sounds correctly & $\mathbf{1}$ \\
\hline$\% 40$ & 60 & $\% 60$ & 90 & $\begin{array}{l}15 \\
0\end{array}$ & uses vocabulary correctly while speaking & 2 \\
\hline$\% 66$ & 99 & $\% 34$ & 51 & $\begin{array}{l}15 \\
0\end{array}$ & Uses correct language structures & 3 \\
\hline $33, \% 63$ & 95 & $66, \% 36$ & 55 & $\begin{array}{l}15 \\
0\end{array}$ & Arrange ideas while talking & 4 \\
\hline $33, \% 43$ & 65 & $66, \% 56$ & 85 & $\begin{array}{l}15 \\
0\end{array}$ & describes a favorite place (class or home ) & 5 \\
\hline$\% 40$ & 60 & $\% 60$ & 90 & $\begin{array}{l}15 \\
0\end{array}$ & tells personal experience & 6 \\
\hline $33, \% 59$ & 89 & $66, \% 40$ & 61 & $\begin{array}{l}15 \\
0\end{array}$ & verbally expresses the storyboard events & 7 \\
\hline$\% 64$ & 96 & $\% 36$ & 54 & $\begin{array}{l}15 \\
0\end{array}$ & $\begin{array}{l}\text { Tells a short story heard by taking into account } \\
\text { the sequence of events and their interdependence }\end{array}$ & 8 \\
\hline $33, \% 43$ & 65 & $66, \% 56$ & 85 & $\begin{array}{l}15 \\
0\end{array}$ & identifies himself to others & 9 \\
\hline $34, \% 35$ & 53 & $66, \% 64$ & 97 & $\begin{array}{l}15 \\
0\end{array}$ & communicate verbally with others & 10 \\
\hline $67, \% 68$ & 103 & $33, \% 31$ & 47 & $\begin{array}{l}15 \\
0\end{array}$ & Nonverbal communication is used appropriately & 11 \\
\hline $67, \% 46$ & 70 & $33, \% 53$ & 80 & $\begin{array}{l}15 \\
0\end{array}$ & expresses his opinion while talking with others & 12 \\
\hline $67, \% 64$ & 97 & $33, \% 35$ & 53 & $\begin{array}{l}15 \\
0\end{array}$ & $\begin{array}{l}\text { speaks without repeating certain words (verbal } \\
\text { necessities) }\end{array}$ & 13 \\
\hline$\% 66$ & 99 & $\% 34$ & 51 & $\begin{array}{l}15 \\
0\end{array}$ & speaks clearly and audibly to listeners & 14 \\
\hline
\end{tabular}

After correcting the speaking test, it was possible to identify the most important speaking skills experienced by the first graders, and thus can be summarized in the following table: 
Table (3)

The speaking skills of first grade primary students are weak

\begin{tabular}{|l|l|}
\hline S.N & speaking skills \\
\hline Level $\mathbf{1}$ - Uses language elements correctly while speaking: \\
\hline 1 & Uses correct language structures. \\
\hline 2 & Arrange ideas while talking. \\
\hline Level II - speaks about life situations: \\
\hline 3 & Orally expresses the events of a storyboard \\
\hline 4 & It tells a short tale that has been listened to taking into account the sequence and interrelationship of events \\
\hline Level 3 - Talk to others: \\
\hline 5 & Nonverbal communication is used appropriately \\
\hline 6 & Speaking without repeating certain words (verbal necessities). \\
\hline 7 & Speaks clear and audible to listeners \\
\hline
\end{tabular}

To find out how well the first grade students were able to speak, and to identify the most important speaking skills experienced by the first grade students, the second question was answered.

2. Results related to the third question: What are the components of the proposed unit to develop some speaking skills of first graders using the language games strategy?

The researcher has prepared a proposed unit to develop some of the speaking skills of first graders using the language games strategy.

4. Results for question four of this research: What is the effectiveness of the proposed unit using the language games strategy in the development of some of the speaking skills of first graders?

To answer this question, the researcher did the following steps:

- Determining the effectiveness of the language games strategy in developing some of the first-grade students' speaking skills by comparing the results of the pre- and post-tests among the experimental group students by applying the $\mathrm{T}$ test to determine the differences between the mean scores of students in the pre and post-test and their significance in each test, the following is shown:

Table (4)

It shows the results of measuring the differences between the pre and post applications of the experimental group in mastery of speaking skills.

\begin{tabular}{|l|l|l|l|l|}
\hline Significance & Freedom & T value & $\begin{array}{l}\text { Stander } \\
\text { deviation2 }\end{array}$ & $\begin{array}{l}\text { Stander } \\
\text { deviation1 }\end{array}$ \\
\hline 01,0 & 48 & 40,44 & 22877 & 16,21 \\
\hline
\end{tabular}

It is clear from the previous table that there are statistically significant differences between pre and post measurements in the experimental group in favor of speaking skills. This result can be explained by the following points:

- Students practice the strategy of language games in the development of some skills to speak effectively through the proposed unit studied by the experimental group based on the procedures of the strategy of language games.

- The language games practiced by students both within the classroom, enabled students of the experimental group to practice a range of mental activities, which significantly affected the ability of the experimental group students to acquire speaking skills.

- Students do not feel any kind of boredom and are replaced by an element of thrill and enjoy learning;

- The language gaming strategy provided interactive activities within the classroom and focused on the skills of communication, discussion, and interaction among students in a positive way. 
- The language gaming strategy provided immediate feedback to students from teachers at class time.

- The language gaming strategy provided students with teamwork skills through effective social communication among students in small groups.

B. Comparison of the results of the post-test in both the control group and the experimental group:

The researcher has reached the results shown in the following table:

Table (5)

It shows the results of measuring differences between the control and experimental groups in first graders acquisition of speaking skills

\begin{tabular}{|l|l|l|l|l|l|}
\hline Significance & T value & variance & Average & $\begin{array}{l}\text { Number of } \\
\text { individuals }\end{array}$ & the group \\
\hline \multirow{2}{*}{01,0} & 94,44 & 90,2 & 92,38 & 50 & Experimental \\
\cline { 3 - 6 } & & 60,6 & 12,17 & 50 & Control \\
\hline
\end{tabular}

The above table shows that there are statistically significant differences between the mean scores of the experimental group and the control group in the post-test in favor of the experimental group in terms of acquiring speaking skills.

This result can be explained by the following points:

1- The students of the experimental group were affected by the program, which shows their ability to acquire speaking skills, due to the nature of the program. While the control group did not apply to the program, but studied in the traditional way, so there is no improvement in the acquisition of these skills.

2. Students in the experimental group have applied language games strategy in Arabic speaking. This developed their speaking skills, increased their abilities to speak positively, and arranged their ideas while they are speaking, while students in the control group did not have this ability.

3 - This result is matching with a lot of the previous research studies. Also the theoretical framework of the current research that the language games strategy has a significant impact on the development of Arabic speaking skills; because of their nature, which is compatible with the nature of speaking skills.

After that the researcher calculated the magnitude of strategy effect used by the square ETA, and through the following equation (Semuel, Siagian, \& Octavia, 2017)

$\mathrm{n}=$

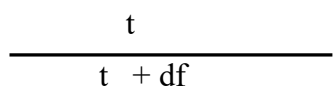

The researcher has reached the results shown in the following table:

Table (6)

Discover the effect of language game strategy on acquiring speaking skills.

\begin{tabular}{|l|l|l|l|l|}
\hline The size of the effect & df & N & The dependent variable & Independent variable \\
\hline Large & $\mathbf{4 7}$ & $\mathbf{9 5 , 0}$ & Acquire speaking skills & Strategy language games \\
\hline
\end{tabular}

Thus, the influence of the language games strategy on the acquisition of speaking skills of first graders is evident.

\section{Research Recommendations:}

From the findings, the following recommendations would be drawn:

A- Offer courses and workshops for teachers and students in order to be trained on how to define the concept of Language Games Strategy before implementation.

B- Prepare training courses to encourage Arabic language teachers to apply games strategy in various classroom situations, and be aware about the importance of these strategies because of their positive impact on students' attitudes.

C- Application of language games which is adopted in this study and others in the teaching of other 
branches of the Arabic language, especially the rules.

\section{References}

Abu-Rabia, S., \& Siegel, L. S. (2003). Reading skills in three orthographies: The case of trilingual ArabicHebrew-English-speaking Arab children. Reading and Writing. https://doi.org/10.1023/A:1025838029204

Al-Momani, A., Hussin, S., \& Hamat, A. (2014). In the Light of Reading Strategies Comprehension improvement (Text Book, Online Material and Smartphone Application). Arab World English Journal.

Bastami Bandpay, A. (2016). Adult's Learning Strategies for Receptive Skill Self-managing or Teachermanaging. In International Journal of Research in English Education.

Boonkit, K. (2010). Enhancing the development of speaking skills for non-native speakers of English. Procedia - Social and Behavioral Sciences. https://doi.org/10.1016/j.sbspro.2010.03.191

Bykova, S. S., Kuvaldina, E. A., Mashkovtseva, L. M., \& Malova, T. V. (2018). Applying the ideas of the developmental teaching at the foreign language lessons to develop students' communicative competence. European Journal of Contemporary Education. https://doi.org/10.13187/ejced.2018.2.275

Chamot, A. U. (2005). Language learning strategy instruction: Current issues and research. Annual Review of Applied Linguistics. https://doi.org/10.1017/S0267190505000061

Cressman, R., \& Apaloo, J. (2018). Evolutionary game theory. In Handbook of Dynamic Game Theory. https://doi.org/10.1007/978-3-319-44374-4_6

https://doi.org/10.1111/tmi.12574

Education, F. L. (2017). Journal of Foreign Language Education and Technology, 2(1), 2017. Journal of Foreign Language Education and Technology.

Fabricatore, C., \& López, X. (2012). Sustainability learning through gaming: An exploratory study. Electronic Journal of E-Learning.

Garzotto, F., Gelsomini, M., Oliveto, L., \& Valoriani, M. (2014). Motion-based touchless interaction for ASD children: A case study. Proceedings of the Workshop on Advanced Visual Interfaces AVI. https://doi.org/10.1145/2598153.2598197

Gros, B. (2007). Digital games in education: Me design of games-based learning environments. Journal of Research on Technology in Education. https://doi.org/10.1080/15391523.2007.10782494

Hardy, Q., \& Hessel, E. (2007). Peer play. Forbes.

Howland, K., \& Good, J. (2015). Learning to communicate computationally with Flip: A bi-modal programming language for game creation. Computers and Education. https://doi.org/10.1016/j.compedu.2014.08.014

Introna, L. D. (2009). Ethics and the Speaking of Things. Theory, Culture \& Society. https://doi.org/10.1177/0263276409104967

Ishrat Aamer Qureshi. (2013). The Importance of Speaking Skill. Gerald Gillis. https://doi.org/10.1093/bioinformatics/btt640

Juzeleniene, S., Mikelioniene, J., Escudeiro, P., \& Carvalho, C. V. de. (2014). GABALL Project: Serious Games Based Language Learning. Procedia - Social and Behavioral Sciences. https://doi.org/10.1016/j.sbspro.2014.05.340

Kim, Y., \& Kellogg, D. (2007). Rules out of roles: Differences in play language and their developmental significance. Applied Linguistics. https://doi.org/10.1093/applin/aml047

Kordaki, M., \& Gousiou, A. (2017). Digital card games in education: A ten year systematic review. Computers and Education. https://doi.org/10.1016/j.compedu.2017.02.011

Marcelioniene, E. (2012). Theoretical aspects of integrated language development in the teaching of reading and writing in primary education. Pedagogika.

McLaren, S., Belling, R., Paul, M., Ford, T., Kramer, T., Weaver, T., ... Singh, S. P. (2013). "Talking a different language": An exploration of the influence of organizational cultures and working practices on transition from child to adult mental health services. BMC Health Services Research. https://doi.org/10.1186/1472-6963-13-254 
Moreno-Manso, J. M., García-Baamonde Sánchez, M. E., Guerrero-Barona, E., \& Blázquez-Alonso, M. (2010). Pragmatic competence and psychosocial adaptation in children in protective care. Salud Mental.

Othman, N., \& Mohamad, K. A. (2014). Thinking skill education and transformational progress in Malaysia. International Education Studies. https://doi.org/10.5539/ies.v7n4p27

Queirós, A., Faria, D., \& Almeida, F. (2017). Strengths and limitations of qualitative and quantitative research methods. European Journal of Education Studies. https://doi.org/10.5281/zenodo.887089

Sadiku, L. M. (2015). The Importance of Four Skills Reading, Speaking, Writing, Listening in a Lesson Hour. European Journal of Language and Literature. https://doi.org/10.26417/ejls.v1i1.p29-31

Sanoudaki, E., \& Thierry, G. (2015). Language non-selective syntactic activation in early bilinguals: the role of verbal fluency. International Journal of Bilingual Education and Bilingualism. https://doi.org/10.1080/13670050.2015.1027143

Sari, M. L., \& Chen, C. T. (2013). Tailored RPG as a supplementary reading pedagogy for teaching English. Workshop Proceedings of the 21st International Conference on Computers in Education, ICCE 2013.

Sarip, M., Rafli, Z., \& Rahmat, A. (2018). Arabic Speaking Material Design Using Content and Language Integrated Learning ( CLIL ). International Journal of Humanities and Cultural Studies.

Semuel, H., Siagian, H., \& Octavia, S. (2017). The Effect of Leadership and Innovation on Differentiation Strategy and Company Performance. Procedia - Social and Behavioral Sciences. https://doi.org/10.1016/j.sbspro.2017.02.171

Smith, A., \& Vaux, T. (2003). Education, Conflict and International Development Contents CONTENTS. Training. https://doi.org/10.1017/CBO9781107415324.004

Smith, M. S. (2009). Opening education. Science. https://doi.org/10.1126/science.1168018

Snyder, I., \& Beavis, C. (2004). Doing literacy online: teaching, learning, and playing in an electronic world. In New dimensions in computers and composition.

Tuan, N. H., \& Mai, T. N. (2015). Factors Affecting Students' Speaking Performance at Le Thanh Hien High School. Asian Journal of Educaitonal Research.

Vandercruysse, S., Vandewaetere, M., Cornillie, F., \& Clarebout, G. (2013). Competition and students' perceptions in a game-based language learning environment. Educational Technology Research and Development. https://doi.org/10.1007/s11423-013-9314-5

Whitton, N. (2014). Digital Games and Learning. In Digital Games and Learning. https://doi.org/10.4324/9780203095935

Ying, L., \& Blanchfield, P. (2010). Learning communication skills by making cartoon films. 4th European Conference on Games Based Learning 2010, ECGBL 2010. 